\title{
HYDROTERMÁLNÍ MINERALIZACE V HORNINÁCH SOLÁŇSKÉHO SOUVRSTVÍ V ZÁPADNÍ ČÁSTI CHŘIBŮ
}

\author{
Hydrothermal mineralization in rocks of the Soláň Formation in the western part of Chřiby \\ Hills
}

\author{
Jana Vlasáková, Kamil Kropáč \\ Katedra geologie PřF UP, 17. listopadu 1192/12, 77146 Olomouc; e-mail: slunicko127@seznam.cz; kamil.kropac@upol.cz
}

(24-44 Bučovice)

Key words: hydrothermal mineralization, fluid inclusions, calcite, Chřiby Hills, Lukov Member, Soláň Formation, Rača Unit

\begin{abstract}
Hydrothermal mineralization sporadically occurs in the western part of Chriby Hills in a form of thin carbonate veins and veinlets hosted by sedimentary rocks of the Lukov Member of the Solán Formation. These veins were found in old quarries and slope debris nearby Koryčany, Cetechovice, and Roštín. The mineral filling of studied veins is formed by calcite or rarely calcite and barite. Based on the investigation of fluid inclusions, hydrothermal calcite crystallized from low-temperature $\left(T_{h}=70-187^{\circ} \mathrm{C}\right)$ and on average low-salinity (0.2-5.6 wt. \% NaCl equiv.) hydrothermal solutions. Hydrothermal veins filling crack systems with the direction NNWSSE or W-E in quarries Holý kopec near Koryčany and Roštín-Chapel are probably post-tectonic. Their origin can be connected to young tectonic events after the termination of main phase of the Alpine Orogeny. Diagenetic origin cannot be excluded in case of calcite vein which fills a bed joint between layers of conglomerate in old quarry $3.5 \mathrm{~km}$ south-southeast from the town Koryčany. The source fluids can be derived from mixing of seawater with diagenetic waters. In case of post-tectonic veins, a contribution of meteoric waters is also possible. In addition, UV-fluorescence microscopy reveals a sporadic presence of inclusion with higher hydrocarbons which exhibits strong blue-white fluorescence. These inclusions document a migration activity of higher hydrocarbons in the northwestern part of the Rača Unit in Chriby Hills.
\end{abstract}

Úvod

Západní část Chřibů představuje z tektonického hlediska zajímavou oblast, na jejiž stavbě se silně uplatnily alpinské horotvorné procesy. Po západním úpatí Chřibů probíhá linie magurského nasunutí račanské jednotky na jednotky vnějších skupin příkrovů. Pro celé území jsou zároveň typické vrásové struktury a výrazná zlomová tektonika. Zlomy často kopírují staré poruchy v podloží př́krovů a vytvárejí dobrý potenciál pro migrace fluid. Tektonické poruchy zde navíc spolu s vhodnou litologií sehrály klíčovou roli při migraci uhlovodíkủ a formování ropných pastí. Výše uvedené faktory vedly $\mathrm{k}$ předpokladu, že by se v zájmové oblasti mohly vyskytovat různé typy hydrotermálních mineralizací dokumentující různé geologické procesy a etapy vývoje. Tato problematika byla řešena v rámci bakalářské práce hlavní autorky (Vlasáková 2015). Předložená krátká zpráva shrnuje nejpodstatnější výsledky z výzkumů hydrotermálních mineralizací v z. části Chřibů vedených v letech 2014-2015.

\section{Geologická situace}

Zájmové území spadá do račanské jednotky magurské skupiny př́krovů flyšového pásma Západních Karpat. V račanské jednotce lze dále rozlišit kaumberské, soláňské, belovežské a zlínské souvrství (obr. 1). Nejstarší kaumberské souvrství reprezentují pestré zelené, šedé a červené jílovce s tenkými vložkami jemně až stř̌edně zrnitých modrošedých drobových až arkózových pískovců. Jednotná sedimentace těchto pelagických až hemipelagických jílovců probíhala od cenomanu do maastrichtu, kdy ji vystřídala faciálně diferenciovaná flyšová sedimentace (Buday et al. 1963a; Stráník et al. 1993). V magurském sedimentačním prostoru se ve stratigrafickém rozsahu maastricht až svrchní paleocén usadilo až $1 \mathrm{~km}$ mocné soláňské souvrství. Pesl (1965) vyčlenil kvưli silné faciální proměnlivosti v soláňském souvrství dvě litologické jednotky: psamiticko-pelitickou, která dnes odpovídá ráztockým vrstvám a psamitickou, která je ekvivalentní lukovským vrstvám. Ve starších ráztockých vrstvách se střídají šedé až zelenošedé, často tmavě chondriticky skvrnité jílovce a drobové pískovce. Podřadně se zde nacházejí i vložky rudých jílovců (Stráník et al. 1993). Nadložní lukovské vrstvy jsou charakteristické střídáním hrubě lavicovitých arkózových či drobových pískovců se skluzovými slepenci s exotickými olistolity. Hrubozrnné slepence obsahují mesozoické (tithon až neokom) valouny až balvany vápenců, fylity, ruly a žuly (Chmelík 1956). Pesl (1965) rozlišil ve spodním oddílu paleogénu v magurském flyši několik litofaciálních zón. $V$ zájmové oblasti se okrajově setkáváme se zónou hostýnskou, výrazně převažuje zóna Tří kamenů. Hostýnská litofaciální zóna je charakteristická přitomností modrošedých pískovců se zvýšeným podílem karbonátového pojiva, oproti tomu sedimenty v zóně Tři kamenů obsahují zvýšené množství biotitu. Ve Chřibech však dochází k částečnému smíšení obou vývojů a provizorní hranice vedená mezi nimi v s. části pohoří není ostrá (Pesl 1965). Ve svrchním paleocénu až středním eocénu došlo $\mathrm{k}$ obnovení sedimentace pestrých jílovců s lokálními polohami arkózových pískovců v podobě belovežského souvrství. V jeho nadloží se uložil až přes $2 \mathrm{~km}$ mocný flyšový komplex zlínského souvrství, reprezentovaný ve Chřibech zejména světle šedými glaukonitickými pískovci a olivově zelenými vápnitými jílovci vsetínských vrstev (střední eocén až spodní oligo- 

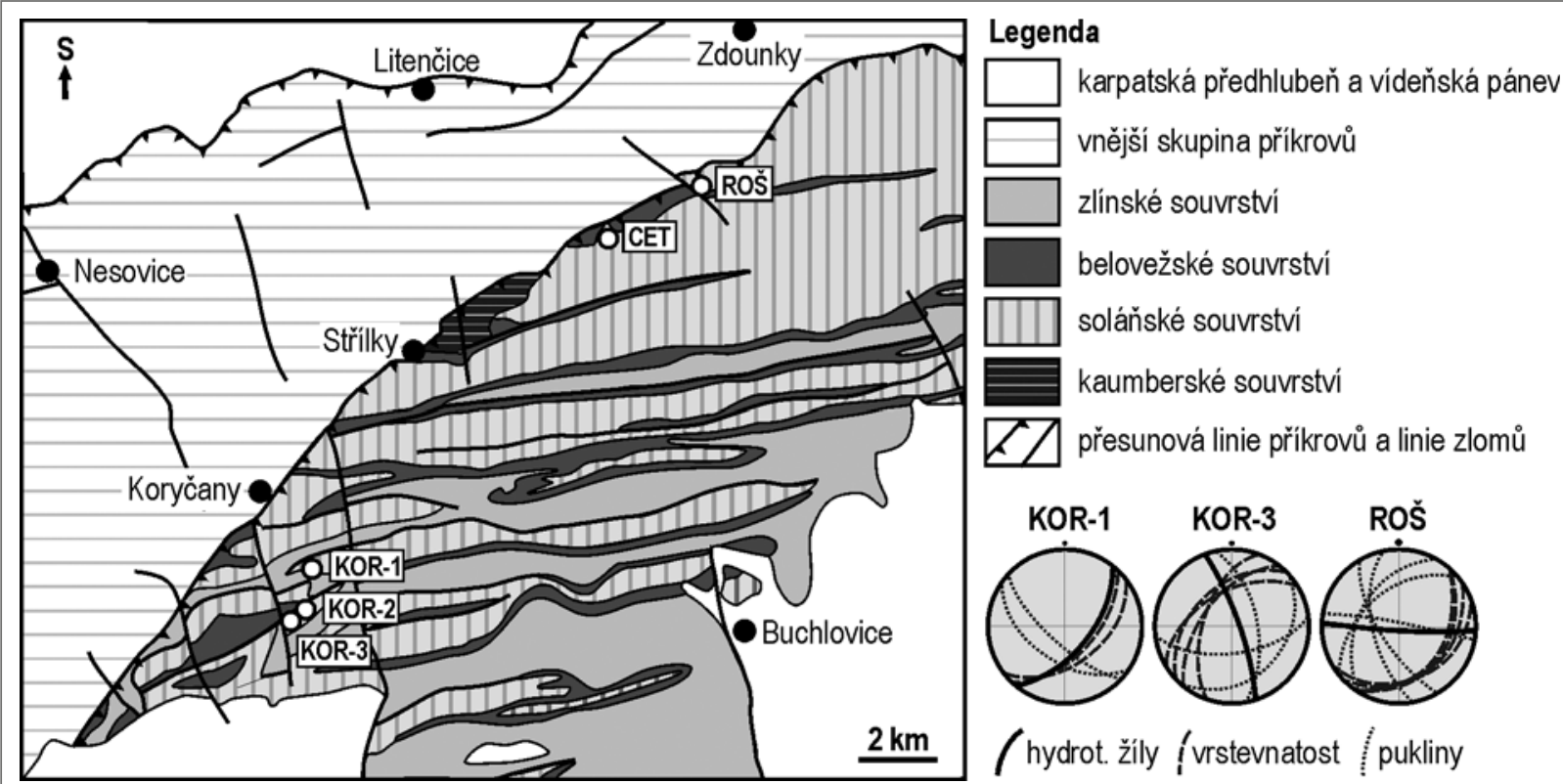

Obr. 1: Schematická mapa geologických jednotek v zájmové oblasti s vyznačenou pozicí výskytu hydrotermálních mineralizací (upraveno podle Budaye et al. 1963b; Dorniče 1992; Havlíčka 1994 a Stráníka 1998). Vpravo dole obloukové diagramy s vynesenými orientacemi kalcitových žil, vrstevnatosti a puklinových systémů na lokalitách Koryčany - lom u lesní cesty (KOR-1), Koryčany Holý kopec (KOR-3) a Roštín - lom za kapličkou (ROŠ). Zobrazeno do spodní hemisféry Lambertovy projekce.

Fig. 1: Schematic map of geological units in the studied area with position of hydrothermal mineralization (modified according to Buday et al. 1963b; Dornič 1992; Havlíček 1994 and Stráník 1998). Right lower part of image: arc diagrams with orientation of calcite veins, bedding, and cracks at sites Koryčany (KOR-1, KOR-3) and Roštín (ROŠ) - displayed in lower hemisphere of the Lambert projection.

cén) a okrajově i sedimenty luhačovických a rusavských vrstev (Stráník et al. 1993). Zlínské souvrství je výrazně zastoupeno především $v \mathrm{j}$. části Chřibủ převážně mimo studované území (Buday et al. 1963a).

Následkem helvetské orogeneze (oligocén) došlo $\mathrm{k}$ ukončení sedimentace $\mathrm{v}$ magurském prostoru a vytvoření embryonální formy magurského př́krovu. Během sávských deformací (hranice eger-eggenburg) byly pod náporem přesouvajícího se magurského př́krovu založeny dílíí príkkrovy ve vnějších jednotkách flyše. Štýrská orogeneze (eggenburg až střední baden) pak dotvořila stavbu magurské skupiny př́krovů do současné podoby. Severozápadní část račanské jednotky byla nasunuta v oblasti Chřibů na jednotky zdouneckou a ždánickou (magurské nasunutí) a společně byly přesunuty přes miocén karpatské předhlubně (Cílek 1954; Buday et al. 1963a; Krystek 1965; Menčík 1969; Stráník et al. 1993). Ve stavbě račanské jednotky zde dominují lineárně uspořádané vrásové struktury ve směru ZJZ-VSV, porušené výraznými zlomovými systémy s orientací SSZ-JJV (Cílek 1954; Buday et al. 1963a; obr. 1).

\section{Metodika}

V rámci terénní etapy výzkumu hydrotermálních mineralizací byly rekognoskovány staré lomy, skalní útvary, výchozy, balvanová moře, strže a koryta potoků v oblasti z. Chřibů mezi obcemi Bohuslavice na JZ a Kostelany na SV. Lokality s výskytem mineralizací in situ byly pečlivě geologicky zdokumentovány včetně provedení strukturně-tektonických měření geologickým kompasem.
Z odebraných vzorků hornin s hydrotermálními žilkami byly na katedře geologie PřF UP v Olomouci zhotoveny leštěné výbrusy. Výbrusové preparáty byly následně studovány pomocí klasické mikroskopie $\mathrm{v}$ procházejícím světle. Chemické složení minerálů bylo stanoveno na elektronové mikrosondě JEOL JXA-8600 s EDX analyzátorem. Při analýze bylo použito urychlovací napětí $15 \mathrm{kV}$ a proud svazku $10 \mathrm{nA}$. Jako standardy byly použity pro: $\mathrm{S}$ - celestin, $\mathrm{Ba}$ - baryt, $\mathrm{Sr}$ - stroncianit, $\mathrm{Mg}$ a Ca - diopsid, Mn - elementární mangan a Fe - magnetit. Fluidní inkluze byly studovány ve štěpných úlomcích kalcitu na mikroskopu Olympus BX 51 s mikrotermometrickou komorou LINKAM THMSG 600. Salinita byla vypočítána z naměřených hodnot tání posledního ledu podle Bodnara (1993). Pro zjištění přítomnosti vyšších uhlovodíkủ byly vzorky studovány na mikroskopu Olympus BX-41, který obsahuje episkopický fluorescenční iluminátor BXRFA a filtr s excitačním rozsahem $330-385 \mathrm{~nm}$.

\section{Charakteristika mineralizací}

Ve studované oblasti se hydrotermální mineralizace vyskytují v podobě karbonátových žil a žilek. Ty byly sporadicky pozorovány ve stěnách starých neaktivních lomů nebo $\mathrm{v}$ samostatných úlomcích hornin volně $\mathrm{v}$ terénu v širším okolí Koryčan, Cetechovic a Roštína, a to výhradně v pískovcích, slepencích a výjimečně také v jílovcích lukovských vrstev soláňského souvrství. Jejich výplň tvoří kalcit, pouze výjimečně kalcit a baryt. Ve skalních útvarech na s. hřebenu Chřibů (např. Gavendova skála, Vlčák, Komínky aj.) ani ve výchozech lukovských vrstev ve stržích či korytech potokủ žilky nebyly nalezeny. Stejně tak negativní 
Tab. 1: Chemické složení analyzovaných karbonátů a barytu.

Tab. 1: Chemical composition of analysed carbonates and barite.

\begin{tabular}{|c|c|c|c|c|c|c|c|c|}
\hline Minerál & \multicolumn{2}{|c|}{ kalcit } & siderit & Minerál & \multirow{2}{*}{\multicolumn{4}{|c|}{$\begin{array}{l}\text { baryt } \\
\text { střed }\end{array}$}} \\
\hline Analýza & stř̌ed & okraj & hornina & Analýza & & & & \\
\hline $\mathrm{MgO}$ & - & 1,32 & 4,48 & $\mathrm{SO}_{3}$ & 33,30 & 34,66 & 34,84 & 32,69 \\
\hline $\mathrm{CaO}$ & 54,81 & 53,49 & 20,00 & $\mathrm{SrO}$ & - & - & 0,63 & - \\
\hline $\mathrm{MnO}$ & 1,85 & - & 4,82 & $\mathrm{BaO}$ & 65,60 & 65,42 & 64,93 & 66,14 \\
\hline $\mathrm{FeO}$ & - & - & 30,81 & - & - & - & - & - \\
\hline suma & 56,66 & 54,81 & 60,12 & suma & 98,90 & 100,08 & 100,40 & 98,84 \\
\hline Vzorec & normal & vván na & (karboná & a 4 (baryt & atomy & sliku ve & zorcové & Inotce \\
\hline $\mathrm{Mg}$ & - & 0,033 & 0,115 & $S$ & 0,993 & 1,004 & 1,003 & 0,986 \\
\hline $\mathrm{Ca}$ & 0,974 & 0,967 & 0,370 & Sr & - & - & 0,014 & - \\
\hline $\mathrm{Mn}$ & 0,026 & - & 0,070 & $\mathrm{Ba}$ & 1,021 & 0,989 & 0,976 & 1,042 \\
\hline $\mathrm{Fe}$ & - & - & 0,445 & - & - & - & - & - \\
\hline catsum & 1,000 & 1,000 & 1,000 & catsum & 2,014 & 1,993 & 1,994 & 2,028 \\
\hline
\end{tabular}

na prrítomnost hydrotermálních mineralizací byly i výchozy ráztockých vrstev soláňského souvrství a dalších souvrství v oblasti (kaumberského, belovežského a zlínského). Tento poznatek není překvapivý, protože pravděpodobnost zachování kalcitových žil ve výchozech značně snižuje malá odolnost tohoto minerálu vưči zvětrávání.

Ve starém stěnovém lomu u lesní cesty cca $3,5 \mathrm{~km}$ jjv. od obce Koryčany byla nalezena kalcitová ložní žíla o průměrné mocnosti $5 \mathrm{~cm}$. Kalcit zde tvoří až $1,5 \mathrm{~cm}$ velké klence bílé až mléčné barvy (vzorek KOR-1). Ložní žíla vyplňuje prostor mezi vrstvami drobnozrnného slepence $s$ vápnitým tmelem a je orientována ve směru $\mathrm{JZ}-\mathrm{SV}$ s úklonem $65^{\circ} \mathrm{kJV}$ (obr. 1). Polohy drobnozrnných slepenců se v lomu stř́idají se silně rozpukanými deskami až lavicemi hrubě zrnitých vápnitých pískovců a hrubozrnných slepenců, které obsahují valouny až bloky jurských vápenců, úlomky rohovců a krystalinických hornin. Zajímavější hydrotermální asociaci poskytl vzorek světle hnědého jemnozrnného pískovce nalezený pod kořeny stromů v lese přibližně $500 \mathrm{~m}$ jz. od chatové oblasti Zavadilka u Koryčan. Hydrotermální žilka v pískovci o mocnosti 3-10 mm je vyplněna čirým, bílým až šedobílým karbonátem a bílým

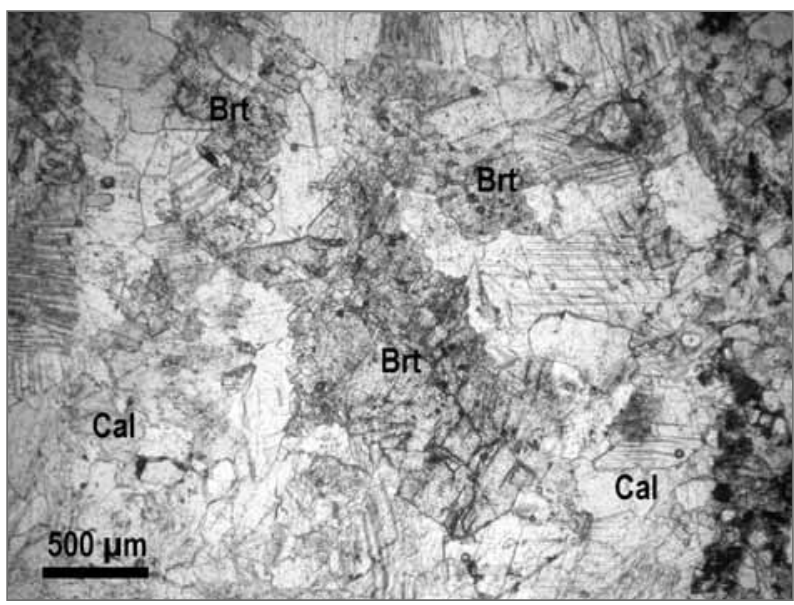

Obr. 2: Hydrotermální žíla vyplněná kalcitem $(\mathrm{Cal})$ a barytem (Brt) nalezená $\mathrm{v}$ úlomku jemnozrnného vápnitého pískovce u Koryčan (KOR-2).

Fig. 2: Hydrothermal vein filled by calcite (Cal) and barite (Brt) in sample of fine-grained calcareous sandstone (KOR-2) which was found nearby the town Koryčany. barytem (vzorek KOR-2). Zrna kalcitu jsou nepravidelná, mají hypautomorfní až xenomorfní omezení a dvojčatné lamelování. Kalcit je chemicky poměrně čistý, přesto lze na základě chemismu rozlišit dvě generace: (i) kalcit na okrajích žilky vykazuje mírně zvýšené obsahy $\mathrm{MgO}(1,32 \mathrm{hm} . \%)$, naproti tomu (ii) zrna ve středu žilky obsahují až 1,85 hm. \% MnO. V hornině při kontaktu s žilkou se vyskytují drobná zrnka karbonátu, která svým chemismem odpovídají sideritu (tab. 1). Baryt tvoř́ tabulkovitá či nepravidelná zrna s hypautomorfním až xenomorfním omezením a nízkým dvojlomem situovaná převážně uprostřed žilky (obr. 2). Z hlediska chemického složení odpovídají analyzovaná zrna barytu s téměř ideální stechiometrií, pouze $\mathrm{v}$ jednom př́padě byla zjištěna malá příměs stroncia (1,4 hm. \% SrO; tab. 1). V oblasti Koryčan byly hydrotermální mineralizace nalezeny ještě v lomu na Holém kopci cca $600 \mathrm{~m}$ z. od hájovny Zavadilka. V lomu se stř́dají středně až hrubě zrnité vápnité pískovce s polohami drobnozrnných až hrubozrnných slepenců s valouny až bloky šedobílých vápenců, úlomky rohovců a krystalinických hornin. Kalcitová žíla (vzorek KOR-3) o mocnosti cca 10-15 mm vyplňuje puklinu ve směru SSZ-JJV s úklonem k VSV ve vrstvě hrubozrnného pískovce (obr. 1). Průběh žíly je př́ímý a je možné jej sledovat přibližně na vzdálenost $1 \mathrm{~m}$. Kalcit na žíle je mléčný až nažloutlý, velikost zrn se pohybuje v rozmezí 1-5 mm. Izometrická zrna kalcitu vykazují dvojčatné lamelování bez známek deformace. Na lokalitě se dále vyskytují drobné kalcitové žilky ve valounech jurských vápenců. Podobné žilky byly objeveny také ve valounech šedozelených a šedomodrých vápenců ve starých lomech u Cetechovic (zmíněné mineralizace však nejsou předmětem této práce). $\mathrm{Na}$ haldách pod lomem zhruba 900 m vjv. od cetechovického kostela byl odebrán vzorek drobnozrnného vápnitého slepence $s$ žilkou vyplněnou šedobílým až mléčným kalcitem o maximální velikosti zrn $3 \mathrm{~mm}$ (CET). V lomu se střídají různě mocné vrstvy střednozrnných až hrubozrnných pískovců s vrstvami drobnozrnných až hrubozrnných vápnitých slepenců, které obsahují valouny a balvany výše uvedených šedozelených a šedomodrých vápenců a úlomky krystalinických hornin. Poslední vzorek hydrotermálního kalcitu (ROŠ) byl získán z žilky v lomu cca 200 m jv. od roštínské kaple. Vystupují zde vrstvy hrubozrnných vápnitých pískovců s tenkými vložkami jílovců a drobnozrnných až hrubozrnných slepenců. Kalcitová žilka o mocnosti pouze $1-4 \mathrm{~mm}$ vyplňuje puklinu ve vrstvě drobnozrnného slepence s orientací $\mathrm{V}-\mathrm{Z}$ a úklonem k J (obr. 1). Velikost zrn bílého až mléčného kalcitu nepřesahuje $1 \mathrm{~mm}$. V polarizačním mikroskopu lze v hypautomorfních až xenomorfních zrnech kalcitu opět pozorovat dvojčatné lamely, které nejsou deformované. Velmi drobné kalcitové žilky byly zastiženy také $\mathrm{v}$ úlomcích jílovců, pískovců a slepenců na haldách v lomu (tyto vzorky nebyly vzhledem $\mathrm{k}$ malé velikosti zrn kalcitu použity pro další studium). 


\section{Fluidní inkluze}

Fluidní inkluze byly studovány pouze $\mathrm{v}$ kalcitu, baryt nebyl vzhledem $\mathrm{k}$ nedostatku materiálu po této stránce zpracován. Ve všech vzorcích byly v kalcitech pozorovány primární (P), pseudosekundární (PS) a sekundární (S) fluidní inkluze. Primární inkluze jsou oblé nebo hranaté s tvarem negativního krystalu (obr. 3). Tyto inkluze tvoř́ shluky nebo se vyskytují solitérně. Za pokojové teploty jsou převážně jednofázové s vodným roztokem $(\mathrm{L})$, pouze ve vzorcích KOR-1, CET a ROŠ se ojediněle objevují i dvoufázové plynokapalné inkluze typu $\mathrm{L}+\mathrm{V}$, které při zahřrivání homogenizují na kapalinu. Teplota homogenizací $\left(\mathrm{T}_{\mathrm{h}}\right)$ těchto inkluzí byla naměřena v rozmezí od 95 do $187^{\circ} \mathrm{C}$ (plynná fáze zaujímala $10-25 \mathrm{obj} . \%)$. K úplnému zamrznutí inkluzí $\left(\mathrm{T}_{\mathrm{f}}\right.$ ) docházelo při teplotách od $-36,5$ do $-48^{\circ} \mathrm{C}$. Poslední krystal ledu odtával při teplotách ( $\mathrm{T}_{\mathrm{m}}$ ice $)-0,4$ až $-3,4$ (tab. 2). Hojně byly pozorovány pseudosekundární fluidní inkluze o velikosti většinou nepřesahující $1,5 \mu \mathrm{m}$. Pseudosekundární inkluze tvoří ve všech vzorcích v kalcitu krátké neprůběžné rádky, které jsou navzájem paralelní nebo se protínají. Sekundární fluidní inkluze tvoří dlouhé řádky, které protínají celá zrna nebo se vyskytují ve shlucích a skupinách. Jsou ploché a mají obvykle protažený nebo nepravidelný tvar. U některých řádků byl pozorován proces zaškrcování inkluzí („necking down“). Většina sekundárních inkluzí je jednofázová (L), pouze ve vzorku KOR-1 byly zastiženy i sekundární inkluze dvoufázové typu $\mathrm{L}+\mathrm{V}$ (plynná fáze zaujímá cca $10 \mathrm{obj} . \%$ ), které homogenizovaly na kapalinu $\left(\mathrm{T}_{\mathrm{h}}\right)$ při teplotách 70 až $88^{\circ} \mathrm{C}$ a zamrzaly $\left(\mathrm{T}_{\mathrm{f}}\right)$ v rozmezí -42 až $-44{ }^{\circ} \mathrm{C}$. Teplota odtávání posledního krystalu ledu ( $\mathrm{T}_{\mathrm{m}}$ ice) byla zaznamenána $\mathrm{v}$ rozmezí $-0,1$ až $-0,7^{\circ} \mathrm{C}(\mathrm{tab} .2)$. Ani v jednom př́padě nebylo možné změřit teplotu eutektika $\left(T_{e}\right)$ kvůli malým velikostem inkluzí (obvykle pod $5 \mu \mathrm{m}$ ) a neostrým fázovým přechodům.

Studované kalcity ze všech vzorků uzavírají rovněž určité množství plochých, nepravidelně protažených a někdy i oválných inkluzí o velikosti až $100 \mu \mathrm{m}$, které jsou při

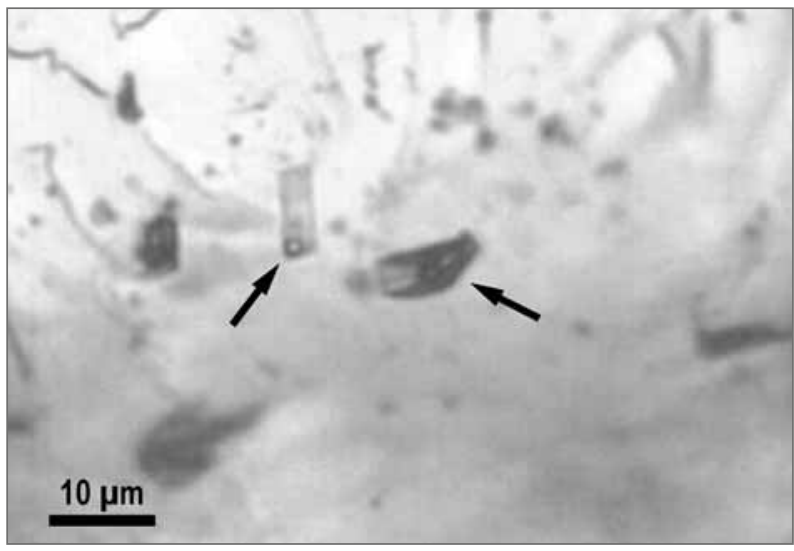

Obr. 3: Př́klady dvoufázových (L+V) primárních inkluzí uzavřených v kalcitu z ložní hydrotermální žíly (vzorek KOR-1).

Fig. 3: Examples of two-phase $(\mathrm{L}+\mathrm{V})$ primary fluid inclusions hosted by calcite from hydrothermal vein which is parallel with bedding (sample KOR-1). pozorování v rovinně polarizovaném světle velmi tmavé a špatně průhledné. Jejich geneze je převážně sekundární, $\mathrm{v}$ případě oválných typů by mohla být i primární. Určení vztahu vůči plynokapalným inkluzím $s$ vodným roztokem je problematické, protože nebylo pozorováno jejich vzájemné protínání. Tmavé špatně průhledné inkluze jeví v UV světle jasně modrobílou fluorescenci. Světle modrá fluorescence byla sporadicky zjištěna také na štěpných trhlinách kalcitu a podél trhlin mezi jednotlivými zrny.

\section{Diskuze}

Chemické složení fluid v inkluzích s vodným roztokem nelze přesněji určit vzhledem $k$ absenci dat o teplotách eutektika. Studované fluidní inkluze však vykazují podobné mikrotermometrické parametry jako fluidní inkluze v hydrotermálních kalcitech na žilkách $\mathrm{v}$ trachyandezitech v bělokarpatské jednotce (lokalita Bučník; Ulmanová 2015) a v pikritech ve slezské jednotce (lokalita Hončova hůrka; Dolníček et al. 2010). Zde zmínění autoři předpokládají na základě naměřených teplot eutektika chemický systém $\mathrm{H}_{2} \mathrm{O}-\mathrm{NaCl}$, prípadně $\mathrm{H}_{2} \mathrm{O}-\mathrm{NaCl}-\mathrm{KCl}$ (Ulmanová 2015), respektive $\mathrm{H}_{2} \mathrm{O}-\mathrm{NaCl}-\mathrm{MgCl}_{2}$ (Dolníček et al. 2010). Jestliže aplikujeme tyto systémy na plynokapalné inkluze z hydrotermálních kalcitů ve Chřibech, salinita uzavřených fluid odpovídá po přepočtu dle Bodnara (1993) hodnotám 0,7 až 5,6 hm. \% NaCl ekv. u primárních a 0,2 až 1,2 hm. \% $\mathrm{NaCl}$ ekv. u sekundárních inkluzí (tab. 2). Jedná se tedy v průměru o nízkosalinní, nízkoteplotní fluida. Vzhledem k pozorovanému trendu v diagramu závislosti $\mathrm{T}_{\mathrm{h}}$ na $\mathrm{T}_{\mathrm{m}}$ ice (obr. 4 - se snižující se teplotou homogenizace se snižuje i teplota tání posledního krystalu ledu) můžeme usuzovat, že tato fluida vznikla mícháním dvou roztoků s odlišnou teplotou a salinitou. Fluidní inkluze v kalcitech z pískovců a slepenců lukovských vrstev vykazovaly mírně nižší teploty tání posledního ledu a homogenizace než fluidní inkluze z kalcitových žilek, které Vlasáková (2015) studovala ve valounech jurských vápencủ na lokalitách u Koryčan a Cetechovic (obr. 4). Další data pro srovnání $\mathrm{z}$ oblasti račanské jednotky nejsou $\mathrm{k}$ dispozici, nicméně jak již bylo naznačeno, naměřené hodnoty homogenizací a salinit jsou rámcově shodné $s$ hodnotami zjištěnými u fluidních inkluzí v hydrotermálních karbonátech, které se vyskytují v sedimentárních a vyvřelých horninách v bělokarpatské (Ulmanová 2015) a slezské jednotce (Polách 2008; Urubek 2009; Urubek - Dolníček 2009; Dolníček et al. 2010). Geneze barytu v karbonátové žilce ve vzorku KOR-2 je nadále předmětem řešení.

Na základě geologické pozice hydrotermálních žil, jejich stavby a charakteru minerální výplně lze interpretovat 


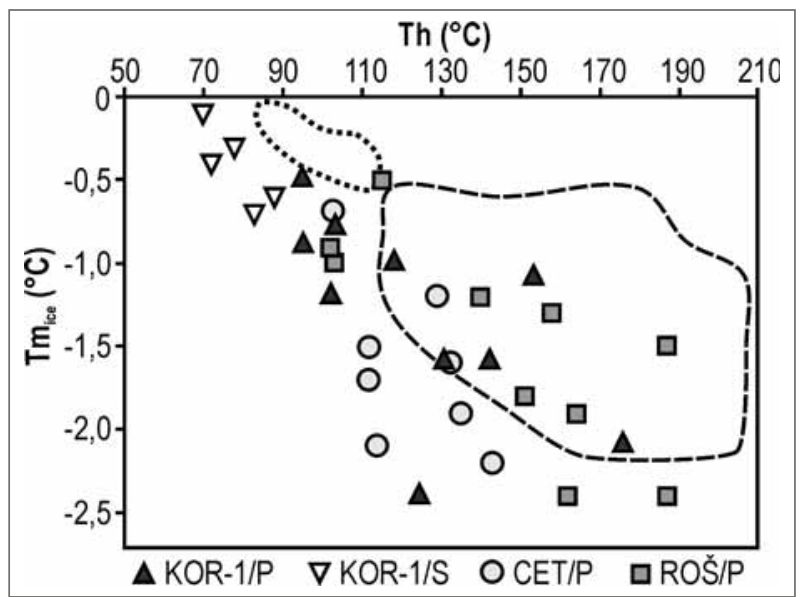

Obr. 4: Diagram $\mathrm{T}_{\mathrm{h}}$ vs. $\mathrm{T}_{\mathrm{m}}$ ice pro primární $(\mathrm{P})$ a sekundární $(\mathrm{S})$ fluidní inkluze uzavřené v kalcitech ve vzorcích KOR-1, CET a ROŠ. Pro srovnání jsou vyneseny teploty homogenizací a teploty tání posledního ledu primárních (čárkovaně) a sekundárních (tečkovaně) fluidních inkluzí z kalcitových žilek ve valounech vápenců z lokalit v okolí Koryčan a Cetechovic (Vlasáková 2015). Fig. 4: $\mathrm{T}_{\mathrm{h}}$ vs. $\mathrm{T}_{\mathrm{m}}$ ice plot for primary $(\mathrm{P})$ and secondary $(\mathrm{S})$ fluid inclusions hosted by calcite from samples KOR-1, CET, and ROŠ. The comparative data represents homogenization temperatures and last-ice melting temperatures for primary (dashed line) and secondary (dotted line) fluid inclusions in calcite veinlets hosted by limestone cobbles from surroundings of Koryčany and Cetechovice (Vlasáková 2015).

genezi mineralizace vzhledem k významným tektonickým událostem. Kalcitové žilky na lokalitách Koryčany-Holý kopec (KOR-3) a Roštín-lom za kapličkou (ROŠ) jsou s největši pravděpodobností posttektonického typu, spjaté s neoidní tektonikou po ukončení hlavních fází alpinského vrásnění a dosunutí flyšových př́ikrovů. Tyto mineralizace vyplňují pukliny orientované ve směru SSZ-JJV a Z-V, které odpovídají směrům hlavních a vedlejších zlomových systémů v oblasti (Havlíček 1994; Stráník 1998; Sanža 2008). Žíly jsou př́mé a nezdeformované, vyplněné granulárním kalcitem bez tektonického rýhování. Dvojčatné lamely v kalcitu navíc nejeví známky deformace. $\mathrm{V}$ obou př́padech by zdrojem fluid mohla být smíšená mořská a diagenetická voda, která se působením tlaků a zvýšených teplot uvolnila ze sedimentu a smísila se s vodou meteorickou. U ložní kalcitové žíly na lokalitě Koryčany - lom u lesní cesty (KOR-1) nemůže být vyloučen pretektonický původ. Tato mineralizace mohla vzniknout již během diageneze za zvýšeného tlaku nadložních vrstev sběrnou krystalizací z hydrotermálních roztokủ generovaných mísením diagenetické a mořské vody. Posttektonické a dia- genetické typy mineralizací se stejnými charakteristikami popisují např̀. Polách (2008) a Urubek (2009) ve flyšových sedimentech slezské jednotky.

Jasně modrobílá fluorescence tmavých inkluzí v UV světle indikuje přitomnost lehkých ropných uhlovodíků (Stasiuk - Snowdon 1997). Jejich výskyt v sekundárních inkluzích a na trhlinách krystalů kalcitu zároveň svědčí o tom, že cirkulace uhlovodíků v systému žíly probíhala i po ukončení krystalizace minerální výplně. Tato zjištění prokazují migrační aktivitu lehkých uhlovodíků v oblasti z. Chřibů. Podobné inkluze s kapalnými vyššími uhlovodíky byly $\mathrm{v}$ magurském flyši zjištěny $\mathrm{v}$ hydrotermálních kalcitech na lokalitě Bučník u Komni v bělokarpatské jednotce (Ulmanová 2015). Ve vnější skupině př́ḱkovů (slezské jednotce) pak ve stronciové mineralizaci v těšínských vápencích u Českého Těšína (Skýpala 2014) a v kalcit-křemen-pyritové mineralizaci ve vyvřelinách těšínitové asociace na lokalitě Stř́brník u Ostravice (Dolníček et al. 2012).

\section{Závěr}

Hydrotermální mineralizace se v z. části Chřibů vyskytují velmi sporadicky v podobě kalcitových žil a žilek, které byly nalezeny v horninách lukovských vrstev soláňského souvrství v okolí Koryčan, Cetechovic a Roštína. $\mathrm{V}$ jednom př́padě byl ve výplni zastižen kromě kalcitu $\mathrm{i}$ baryt. Žilný kalcit krystaloval $\mathrm{z}$ nízkoteplotních $\left(\mathrm{T}_{\mathrm{h}}=\right.$ $\left.70-187^{\circ} \mathrm{C}\right)$ a v průměru nízkosalinních $(0,2-5,6 \mathrm{hm}$. \% $\mathrm{NaCl}$ ekv.) roztoků. Geneze hydrotermálních žil vázaných na puklinové systémy směru SSZ-JJV nebo Z-V v lomech na Holém kopci u Koryčan a za kapličkou u Roštína je pravděpodobně spjatá $s$ mladou neoidní tektonikou po ukončení hlavních fází alpinského vrásnění. U kalcitové ložní žíly v lomu u lesní cesty jv. od Koryčan nelze vyloučit diagenetický původ. Zdroj hydrotermálních roztoků lze patrně spatřovat $\mathrm{v}$ mísení mořské a diagenetické vody, $v$ př́padě posttektonických žil pak i s možným př́spěvkem zasakujících meteorických vod. Tmavé inkluze obsahující lehké ropné uhlovodíky prokazují migrační aktivitu vyšších uhlovodíkủ v sz. části račanské jednotky v oblasti z. Chřibů.

\section{Poděkování}

Autoři článku děkují recenzentům P. Pořádkovi a M. Bubíkovi a editorưm P. Tomanové Petrovéa H. Gilikovéza kritické připomínky, které přispěly $k$ jeho zkvalitnění. Práce byla podpořena projektem IGA_PrF_2016_014. 
Literatura

Bodnar, R. J. (1993): Revised equation and table for determining the freezing point depression of $\mathrm{H}_{2} \mathrm{O}-\mathrm{NaCl}$ solutions. - Geochimica et Cosmochimica Acta, 57, 683-684.

Buday, T. - Benešová, E. - Březina, J. - Cicha, I. - Čtyroký, O. - Dornič, J. - Dvořák, J. - Eliáš, M. - Hanzlíková, E. - Jendrejáková, O. - Kačura, G. - Kamenický, J. - Kheil, J. - Köhler, E. - Kullmanová, A. - Mahel', M. - Matějka, A. - Paulík, J. - Salaj, J. - Scheibner, E. - Scheibnerová, V. - Stehlík, O. - Urbánek, L. - Vavřínová, M. - Zelman J. (1963a): Vysvětlivky k přehledné mapě ČSSR $1: 200$ 000. - Ústřední ústav geologický. Praha.

Buday, T. - Cicha, I. - Paulík, J. - Dornič, J. - Dvořák, J. - Kamenický, J. - Mahel', M. - Matějka, A. - Salay, J. - Scheibner, E. - Zelman, J. (1963b): Geologická mapa ČSSR 1 : 200 000, M-33-XXX Gottwaldov. - Ústřední ústav geologický. Praha.

Cílek, V. (1954): Magurské nasunutí na jihozápadním konci Chřibů. - Práce Ústavu pro naftový výzkum, 1-3, 3-73.

Dornič, J. (1992): Geologická mapa ČR 1:50 000, list 24-42 Kojetín. - Český geologický ústav. Praha.

Dolníček, Z. - Urubek, T. - Kropáč, K. (2010): Post-magmatic hydrothermal mineralization associated with Cretaceous picrite (Outer Western Carpathians, Czech Republic): interaction between host rock and externally derived fluid. - Geologica Carpathica, 61, 4, 327-339.

Dolníček, Z. - Kropáč, K. - Janíčková, K. - Urubek, T. (2012): Diagenetic source of fluids causing the hydrothermal alteration of teschenites in the Silesian Unit, Outer Western Carpathians, Czech Republic: Petroleum-bearing vein mineralization from the Stř́brník site. - Marine and Petroleum Geology, 37, 27-40.

Havlíček, P. (1994): Geologická mapa ČR 1 : 50 000, list 25-33 Uherské Hradiště. - Český geologický ústav. Praha.

Chmelík, F. (1956): Geologie cetechovických bradel a jejich okolí. - Sborník Ústředního ústavu geologického, 23, 2, 533-568.

Krystek, I. (1965): Výzkum sedimentů západní části magurského flyše a otázky jejich genese. - Folia př́rodovědecké fakulty Univerzity J. E. Purkyně v Brně, 4, 9, 1-72.

Menčík, E. (1969): O některých tektonických problémech v magurské skupině flyšové. - Geologické práce, Správy, 47, 91-128.

Pesl, V. (1965): Litofaciální zóny spodního oddílu paleogénu ve vnějších jednotkách západní části magurského flyše. - Sborník geologických vied, Západné Karpaty, 3, 179-212.

Polách, M. (2008): Hydrotermální mineralizace ve východní části Moravskoslezských Beskyd (Vnější Západní Karpaty). - MS, diplomová práce. PřF UP Olomouc.

Sanža, L. (2008): Tektonika střední části Chřibů (vněkarpatský flyš). - MS, diplomová práce. PřF MU Brno.

Skýpala, J. (2014): Stronciová mineralizace těšínských vápencủ (slezská jednotka Vnějších Západních Karpat). - MS, bakalářská práce. PřF UP Olomouc.

Stasiuk, L. D. - Snowdon, L. R. (1997): Fluorescence micro-spectrometry of synthetic and natural hydrocarbon fluid inclusions: crude oil chemistry, density and application to petroleum migration. - Applied Geochemistry, 12, 229-241.

Stráník, Z. - Menčík, E. - Eliáš, M. - Adámek, J. (1993): Flyšové pásmo Západních Karpat, autochtonní mesozoikum a paleogén na Moravě a ve Slezsku. - In: Přichystal, A. - Obstová, V. - Suk, M. (eds): Geologie Moravy a Slezska, 107-122, Moravské zemské muzeum a Masarykova univerzita.

Stráník, Z. (1998): Geologicka mapa ČR 1 : 50 000, list 24-44 Bučovice. - Český geologický ústav. Praha.

Ulmanová, J. (2015): Podmínky vzniku vybraných mineralizací z lomu Bučník u Komni. - MS, bakalářská práce. PřF UP Olomouc.

Urubek, T. (2009): Hydrotermální mineralizace v západní části Moravskoslezských Beskyd (Vnější západní Karpaty). - MS, diplomová práce. PřF UP Olomouc.

Urubek, T. - Dolníček, Z. (2009): Hydrotermální mineralizace v jílovcích lhoteckého souvrství u Choryně (slezská jednotka, Vnější Západní Karpaty). - Geologické výzkumy na Moravě a ve Slezsku, 16, 81-84.

Vlasáková, J. (2015): Hydrotermální mineralizace v západní části Chřribů. - MS, bakalářská práce. PřF UP Olomouc. 